\title{
Environmental Information Disclosure and Auditing of Listed Companies in Heavy Pollution Industries
}

\author{
ShiXiao \\ Beijing Jiaotong University, China
}

\begin{abstract}
Concentrating on environmental issues in financial statement auditing is the main way for auditors to fulfill their environmental protection responsibilities. By studying the impact of environmental information disclosure on audit fees and audit opinions, we can infer how closely the auditors focus on environmental matters to some extent. In this paper, listed companies with serious pollution in A-share market in China from 2014 to 2019 are selected as research samples to explore the correlation among environmental-related information disclosure, audit fees and audit opinions. Through empirical analysis, it is found that the level of environmental information disclosure of listed companies in heavily polluted industries is positively correlated with the audit fees, and negatively correlated with the publication of non-standard audit opinions.
\end{abstract}

\section{Introduction}

Compared with traditional economic operation mode, low-carbon economy is an innovative economic mode, technological mode and social development mode. The Ministry of Environmental Protection's Measures for Environmental Information Disclosure (Trial) stipulates that "enterprises ought to disclose environmental-related information timely and accurately in conformity to the principle of combining voluntary disclosure with compulsory disclosure".

The disclosure of environmental-related information can bring certain economic consequences. Al-Tuwaijri et al. found that environmental performance is positively correlated with the level of corporate environmental-related information disclosure[1]. Lorraine et al. found that the disclosure of environmental performance information will lead to the change of company stock price, and good environmental performance information will lead to positive market reaction[2]. Sharman found that the disclosure of high-quality environmental information by enterprises can effectively reduce environmental risks, avoid penalties and restrictive policies of environmental protection departments[3]. Other scholars found that environmental information affects a firm's value positively[5], and there is a significant negative correlation between environmental information disclosure and debt costs [6].

Related researches mainly investigate the impact of environmental information disclosure on enterprise value and investors, while few studies pay attention to the influence of enterprise environmental information on auditing. By establishing multiple regression model, this paper empirically studies the influence of environmental information disclosure on audit fees and audit opinions in companies with serious environmental pollution.

\section{Hypothesis presentation}

According to the research of Simunic's classic paradigm, the main factors affecting audit fees are: audit cost, audit risk and the normal profits. Compared with the general audit of financial statements, auditors need to do more work and invest more resources in the process of auditing environmental information disclosure, so as to express appropriate and reasonable audit opinions. That will increase audit costs, increase audit risks, and lead to an increase in audit fees. For example, auditors need to understand the environmental problems and examine the environmental laws and regulations applicable to the audited units to judge whether they comply with relevant laws and policies. This greatly increases the work content and working time of auditors, and the increase in work will eventually be reflected in the audit fees. Based on this, hypothesis 1 is put forward.

H1: The degree of environmental information disclosure of listed companies in heavily polluted industries is positively correlated with audit fees.

The type of audit opinion is affected by two factors: first, the professional ability of auditors, whether the auditor has enough competence to judge whether there is a major misstatement caused by errors or fraud in the financial statements; Second, the possibility of auditors to report or disclose violations, that is, whether auditors remain independent in the process of auditing and provide objective and fair audit opinions. Environmental audit involves multi-disciplinary, so auditors face many challenges in confirming and measuring environmental

\footnotetext{
* Corresponding author: 18362087631@163.com
} 
information. At present, although some relevant standards have been put forward in China, there is no specific standard for auditing environmental information financial statements, which mainly depends on professional judgment, so auditors will express their audit opinions more cautiously. In addition, because the confirmation and measurement of environmental information usually involves more technical and physical data, which is a great challenge for auditors themselves, so auditors may choose to express audit opinions more carefully when faced with environmental matters. Based on this, hypothesis 2 is put forward.

$\mathrm{H} 2$ : The degree of environmental information disclosure of listed companies in heavily polluted industries is negatively correlated with non-standard audit opinions.

\section{Research design}

\subsection{Sample selection and data sources}

the paper takes the listed companies in heavily polluted industries in A-share market from 2014 to 2019 as research samples, eliminates the missing data samples, and finally gets 2138 samples. The basic financial data needed in this paper comes from CSMAR. The environmental information disclosure index of enterprises are obtained by consulting annual reports, social responsibility reports, environmental reports and sustainable development reports manually. The data processing tool is Stata15.0.

\subsection{The definition of variables}

\subsubsection{Explained variables}

The paper mainly researches the impact of environmental information disclosure on auditing, so the interpreted variables of the study are audit fees and audit opinion. Audit expenses are expressed by AF, audit opinions are expressed by OP, and audit opinions are divided into standard audit opinions and non-standard audit opinions.

\subsubsection{Explanatory variables}

In this paper, the environmental information disclosure index is regarded as alternative variables of environmental information disclosure level. The content analysis method is adopted when studying the quantitative degree of environmental information. On the basis of consulting the annual financial reports and independent environmental reports (social responsibility reports, sustainable development reports and environmental reports) published by companies with serious environmental pollution, the company will be graded for whether it has disclosed the eight contents required to be disclosed. If it has disclosed the corresponding contents, it will get 1 score, and if it has not disclosed it, it will get 0 score. In this paper, the methods of the above scholars are used for reference, and the companies that disclose social responsibility reports or sustainable development reports are given 1 point, and the companies that disclose environmental reports are given 2 points. Since companies will only disclose one of the independent environmental reports at most, the optimal disclosure score of sample companies is 10 points.

Table 1. Calculation Table of Environmental Information Disclosure Index (EDI)

\begin{tabular}{|c|c|}
\hline $\begin{array}{c}\text { Serial } \\
\text { number }\end{array}$ & Disclosure content \\
\hline 1 & Three wastes income and tax relief \\
\hline 2 & $\begin{array}{l}\text { Completion of energy conservation and } \\
\text { emission reduction }\end{array}$ \\
\hline 3 & $\begin{array}{l}\text { Environmental protection funds, subsidies } \\
\text { and incentives }\end{array}$ \\
\hline 4 & Specific amount of greening fee \\
\hline 5 & Specific amount of sewage charges \\
\hline 6 & Implementation effect of cleaner production \\
\hline 7 & Environmental pollution and litigation costs \\
\hline 8 & Investment in environmental technology \\
\hline \multicolumn{2}{|c|}{$\begin{array}{l}\text { Item } 1 \text { : If the company discloses the above-mentioned items } \\
1-8 \text { that are required to be disclosed in the annual financial } \\
\text { report, } 1 \text { point is awarded for each item disclosed, and } 0 \\
\text { points for non-disclosure. }\end{array}$} \\
\hline \multicolumn{2}{|c|}{$\begin{array}{l}\text { Item 2: If a social responsibility report or sustainability } \\
\text { report is disclosed to the outside world, } 1 \text { point is added, } \\
\text { and } 0 \text { points for non-disclosure. }\end{array}$} \\
\hline \multicolumn{2}{|c|}{$\begin{array}{l}\text { Item } 3 \text { If the environmental report is disclosed to the outside, } \\
2 \text { points will be added, and } 0 \text { points for non-disclosure. }\end{array}$} \\
\hline \multicolumn{2}{|c|}{$\begin{array}{r}\text { Total score }=\text { Item } 1 \text { score }+ \text { Item } 2 \text { score }+ \text { Item } 3 \text { score } \\
\text { Disclosure index EDI = total company score } / \text { optimal } \\
\text { disclosure score }(10 \text { points })\end{array}$} \\
\hline
\end{tabular}

\subsubsection{Control variables}

In the selection of control variables, this paper summarizes the existing achievements of scholars on the influencing factors of audit opinions and audit fees. The research on audit fees started from Simunic(1980), and he thought that the factors which affect the audit fees were audit cost, risk and the normal profits of accounting firms. The existing research at home and abroad have made a thorough inquiry in factors affecting audit opinions, mainly focusing on financial characteristics and company characteristics. The final control variables are shown in the following table. 
Table 2. Summary of variables

\begin{tabular}{|c|c|c|c|}
\hline Variable type & $\begin{array}{c}\text { Variable } \\
\text { name }\end{array}$ & $\begin{array}{l}\text { Identific } \\
\text { ation }\end{array}$ & $\begin{array}{l}\text { Variable } \\
\text { meaning }\end{array}$ \\
\hline \multirow[t]{2}{*}{$\begin{array}{c}\text { Interpreted } \\
\text { variable } \\
\end{array}$} & $\begin{array}{c}\text { Audit } \\
\text { expenses }\end{array}$ & $\ln \mathrm{AF}$ & $\begin{array}{c}\text { Natural logarithm } \\
\text { of audit cost }\end{array}$ \\
\hline & $\begin{array}{l}\text { Audit } \\
\text { opinion }\end{array}$ & OP & $\begin{array}{l}\text { The non-standard } \\
\text { opinion is } 1 \text {, and } \\
\text { the standard } \\
\text { opinion is } 0\end{array}$ \\
\hline $\begin{array}{l}\text { Explanatory } \\
\text { variable }\end{array}$ & $\begin{array}{c}\text { Environm } \\
\text {-ental } \\
\text { informati } \\
\text { on } \\
\text { disclosure } \\
\text { index } \\
\end{array}$ & EDI & $\begin{array}{c}\text { Eight } \\
\text { environmental } \\
\text { information } \\
\text { disclosure scores }\end{array}$ \\
\hline \multirow[t]{8}{*}{$\begin{array}{l}\text { Control } \\
\text { variable }\end{array}$} & $\begin{array}{l}\text { Company } \\
\text { size }\end{array}$ & lnAssets & $\begin{array}{l}\text { Natural logarithm } \\
\text { of total assets }\end{array}$ \\
\hline & $\begin{array}{l}\text { Asset-liab } \\
\text { ility ratio }\end{array}$ & LEV & $\begin{array}{c}\text { Total } \\
\text { liabilities/total } \\
\text { assets at year end } \\
\end{array}$ \\
\hline & $\begin{array}{l}\text { Return on } \\
\text { net assets }\end{array}$ & ROE & $\begin{array}{c}\text { Net profit/net } \\
\text { assets }\end{array}$ \\
\hline & $\begin{array}{l}\text { Ratio of } \\
\text { accounts } \\
\text { receivable } \\
\text { to total } \\
\text { assets }\end{array}$ & $\begin{array}{l}\text { Receiva } \\
\text { ble }\end{array}$ & $\begin{array}{l}\text { Accounts } \\
\text { receivable/total } \\
\text { assets }\end{array}$ \\
\hline & Firm size & BID4 & $\begin{array}{l}\text { If it is the } \\
\text { "International Big } \\
\text { Four", take } 1 \text {, } \\
\text { otherwise take } 0\end{array}$ \\
\hline & $\begin{array}{l}\text { Type of } \\
\text { previous } \\
\text { audit } \\
\text { opinion } \\
\end{array}$ & PAO & $\begin{array}{l}\text { The non-standard } \\
\text { opinion is } 1 \text {, and } \\
\text { the standard } \\
\text { opinion is } 0\end{array}$ \\
\hline & $\begin{array}{l}\text { Change of } \\
\text { firm }\end{array}$ & Change & $\begin{array}{l}\text { The value of } \\
\text { change is } 1 \text {, } \\
\text { otherwise it is } 0\end{array}$ \\
\hline & $\begin{array}{l}\text { Is there a } \\
\text { loss }\end{array}$ & Loss & $\begin{array}{l}\text { The value of the } \\
\text { incurred loss is } 1 \text {, } \\
\text { otherwise it is } 0\end{array}$ \\
\hline
\end{tabular}

\subsection{Research design}

The multiple regression model established for hypothesis $\mathrm{H} 1$ is:

$\ln \mathrm{AF}=\beta 0+\beta 1 \mathrm{EDI}+\beta 2 \ln$ Assets $+\beta 3 \mathrm{LEV}+\beta 4 \mathrm{ROE}+$ $\beta$ Receivable $+\beta 6 \mathrm{BIG} 4+\beta 7 \mathrm{PAO}+\beta 8 \mathrm{Change}+$ $\beta$ Change $+\varepsilon$

The multiple regression model established for hypothesis $\mathrm{H} 2$ is:

$\mathrm{OP}=\beta 0+\beta 1 \mathrm{EDI}+\beta 2 \ln$ Assets $+\beta 3 \mathrm{LEV}+\beta 4 \mathrm{ROE}+$ $\beta 5$ Receivable $+\beta 6 \mathrm{BIG} 4+\beta 7 \mathrm{PAO}+\beta 8 \mathrm{Change}+$ $\beta 9$ Change $+\varepsilon$

\section{Empirical results and analysis}

\subsection{Descriptive statistics}

In this paper, the variables of model 1 and model 2 are statistically described, and the results have been listed in table3. The maximum value, the minimum value and the average value of the audit fees are 18.924, 12.237 and 16.814 , from which it can be concluded that most of the sample enterprises have higher audit fees. The maximum value of audit opinion is 1 , the minimum value is 0 , the average value is 0.031 , and the average value is close to the minimum value, so most of the sample enterprises have obtained the standard audit opinion. And the average value of environmental information disclosure index is 0.432 , indicating that the overall disclosure level of sample enterprises is moderately low. Besides, the standard deviation is 1.875 , indicating that the environmental information disclosure level of different companies varies greatly. In addition, this paper also analyzes the relationship between explanatory variables and control variables, and the results show that the correlation degree of all variables is within an acceptable range, and no severe multicollinearity problem was found.

Table 3. Descriptive statistics of variables

\begin{tabular}{|c|c|c|c|c|c|}
\hline Variable & $\mathbf{N}$ & Min & Max & Mean & Std.Dev. \\
\hline $\ln A F$ & 2138 & 12.237 & 18.924 & 16.814 & 1.271 \\
\hline OP & 2138 & 0 & 1 & 0.031 & 0.163 \\
\hline EDI & 2138 & 0 & 1 & 0.432 & 1.875 \\
\hline $\ln$ Assets & 2138 & 12.253 & 28.63 & 24.647 & 0.531 \\
\hline LEV & 2138 & 0.035 & 1,675 & 0.126 & 0.321 \\
\hline ROE & 2138 & -4.638 & 2.167 & 0.087 & 0.129 \\
\hline $\begin{array}{c}\text { Receiva } \\
\text { ble }\end{array}$ & 2138 & 0 & 0.432 & 0.061 & 0.052 \\
\hline BID4 & 2138 & 0 & 1 & 0.032 & 0.168 \\
\hline PAO & 2138 & 0 & 1 & 0.081 & 0.054 \\
\hline Change & 2138 & 0 & 1 & 0.032 & 0.163 \\
\hline Loss & 2138 & 0 & 1 & 0.039 & 0.143 \\
\hline
\end{tabular}

\subsection{Multiple regression analysis}

According to the regression results of model one, the regression coefficient of environmental information disclosure index is 0.067 , which is significant at the level of 0.05 , and the degree of environmental information disclosure is positively correlated with audit fees. The reason is that the higher the degree of disclosure of environmental information by audit clients, the more resources and energy the auditors need to invest when implementing audit procedures on environmental information, which leads to increased audit fees. So hypothesis 1 has been verified. And by analyzing the regression results of model two, the regression coefficient of environmental information disclosure index is -0.057 , which is significant at the level of 0.1 , reflecting that the more detailed the environmental information disclosure of the audited entity is, the more auditors are inclined to issue standard audit opinions, thus hypothesis 2 is verified. 
Table 4. Multiple regression results

\begin{tabular}{|c|c|c|}
\hline VARIABLES & y1 & y2 \\
\hline \multirow[t]{2}{*}{ EDI } & $0.067 * * *$ & $-0.057 * *$ \\
\hline & $(-4.19)$ & $(-3.14)$ \\
\hline \multirow[t]{2}{*}{ lnAssets } & $-0.311 * * *$ & $-0.322 * * *$ \\
\hline & $(-5.72)$ & $(-3.52)$ \\
\hline \multirow[t]{2}{*}{ LEV } & -0.026 & -0.125 \\
\hline & $(-1.32)$ & $(-1.28)$ \\
\hline \multirow[t]{2}{*}{ ROE } & -0.001 & 0.034 \\
\hline & $(-0.02)$ & $(0.08)$ \\
\hline \multirow[t]{2}{*}{ Receivable } & $-7.586 * * *$ & $-7.607 * * *$ \\
\hline & $(-7.82)$ & $(-7.86)$ \\
\hline \multirow[t]{2}{*}{ BID4 } & $0.014 * * *$ & $0.013 * * *$ \\
\hline & $(3.76)$ & $(3.23)$ \\
\hline \multirow[t]{2}{*}{ PAO } & $-1.040 * * *$ & $-1.032 * * *$ \\
\hline & $(-17.29)$ & $(-8.15)$ \\
\hline \multirow[t]{2}{*}{ Change } & $-8.345^{* * *}$ & $-4.351 * * *$ \\
\hline & $(-31.74)$ & $(-28.71)$ \\
\hline \multirow[t]{2}{*}{ Loss } & $-0.430 * * *$ & $-0.429 * * *$ \\
\hline & $(-8.18)$ & $(-8.17)$ \\
\hline Observations & 2138 & 2138 \\
\hline $\operatorname{Adj}-\mathrm{R}$ & 0.2221 & 0.2233 \\
\hline
\end{tabular}

\subsection{Robustness test}

In order to further test the robustness of the model and the reliability of the conclusions, this paper conducts a robustness test on the original model. In this study, the chemical and metallurgical industries have a large number of sub-samples and are also the focus in enterprises with serious environmental pollution. Therefore, these two industry sub-samples are selected for robustness testing. The conclusions obtained through the robustness test of the sub-data of the metallurgy and chemical industries are basically consistent with the conclusions obtained from the full sample in the previous article, reflecting that the model used in this paper has strong robustness, thus the research conclusions have good credibility.

\section{Conclusion}

Environmental information disclosure has a significant influence on auditing. The more detailed the environmental information disclosure of the audited entity, the more resources and energy the auditors need to invest in the risk assessment process, and the more professional judgments and estimates they need to make when confirming and measuring environmental matters. At the same time, auditors need to collect relevant evidence to prove that the financial statements and environmental reports of enterprises have objectively and fairly revealed the environmental information of enterprises. Compared with the general audit of financial statements, the workload and working hours of auditors will increase, prompting them to raise audit fees. The more detailed the environmental information, the easier it is for auditors to gain "identity". On the contrary, if the environmental information disclosed by enterprises is too brief, it will send a signal to auditors that firms are unable to disclose environmental information or enterprises intentionally conceal environmental information, and auditors tend to provide non-standard opinions.

This article believes that government regulatory agencies should strengthen the supervision of environmental-related information disclosure, not only to standardize the form of environmental information disclosure, but also to focus on the supervision of the quality of environmental-related information disclosure in the annual financial statements. This will help urge companies to better fulfill their environmental protection responsibilities. In addition, although the auditing standards stipulate that auditors should pay attention to environmental matters related to financial statements when auditing, the degree of attention to environmental information in practice is insufficient. Therefore, auditors should improve their environmental awareness and professional skills so as to better fulfill their social supervision responsibilities.

\section{References}

1. Al-Tuwaijri S A, Christensen T E, Hughes K I. The relations among environmental disclosure, environmental performance, and economic performance: a simultaneous equations approach [J]. Social science Electronic Publishing, 2004, 29(5-6):447-471.

2. Lorraine N H J, Collison D J, Power D M. An analysis of the stock market impact of environmental performance information [J]. Accounting Forum, 2004, 28(1):7-26.

3. Jose A, Lee S M. Environmental Reporting of Global Corporations: A Content Analysis based on Website Disclosures [J]. Journal of Business Ethics, 2007, 72(4):307-321.

4. Simunic D A. The pricing of audit services: Theory and evidence [J]. Journal of Accounting Research, 1980, 18(1):161-190.

5. Wang, Mao-Chang. The relationship between environmental information disclosure and firm valuation: the role of corporate governance[J]. Quality \& Quantity, 2016, 50(3):1135-1151.

6. Fonseka M, Rajapakse T, Richardson G . The effect of environmental information disclosure and energy product type on the cost of debt: Evidence from energy firms in China [J]. Pacific-Basin Finance Journal, 2019:159-182. 